\title{
Double switch operations: Should we perform physiologic or anatomic repair in congenitally corrected transposition of the great arteries
}

\author{
Double switch ameliyatları: Büyük arterlerin doğuştan düzeltilmiş transpozisyonunda \\ fizyolojik düzeltme mi, anatomik düzeltme mi yapalım?

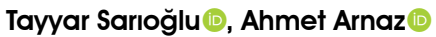 \\ Department of Cardiovascular Surgery, Division of Pediatric Cardiovascular Surgery, \\ Acıbadem Mehmet Ali Aydınlar University, Istanbul, Turkey
}

\begin{abstract}
The seeking for the optimal surgical treatment of congenitally corrected transposition of the great arteries (cTGA) is ongoing. Physiologic (conventional) repair approaches, leaving the morphologic right ventricle (MRV) on the systemic circulation side, cause systemic ventricle and tricuspid valve failure, particularly in the long-term. Double Switch operations (anatomic repair) were aimed to convert the morphologic left ventricle to systemic ventricle and MRV to pulmonic ventricle. Gradual improvement in the early and midterm results of double switch operations in the last 20 years rendered anatomic repair to become a preferred procedure. Thanks to the preservation of ventricular functions through anatomic repair, patients with congenitally cTGA may survive longer with normal/near normal functional capacity. However, studies with larger sample size and longer follow-up duration are required to establish a more definite judgement.
\end{abstract}

Keywords: Arterial switch; atrial switch; congenitally corrected transposition of the great arteries; double switch.

Late results of conventional physiologic corrective surgery for congenitally corrected transposition of great arteries (cTGA) have led to major concerns and a quest for further investigation. ${ }^{[1-10]}$

Due to atrioventricular (AV) discordance and ventriculoarterial (VA) discordance systemic ventricular dysfunction of the morphologic right ventricle (MRV) structure and systemic AV valve
$\ddot{O} Z$

Doğuştan düzeltilmiş büyük arterlerin transpozisyonunun (cTGA) optimal cerrahi tedavisine yönelik arayışlar devam etmektedir. Fizyolojik (konvansiyonel) düzeltme yaklaşımlarında, morfolojik sağ ventrikülün (MRV) sistemik dolaşım tarafında kalıyor olması, özellikle geç dönemde, sistemik ventrikül ve triküspit kapak yetersizliği ile sonuçlanmaktadır. Double switch (anatomik düzeltme) ameliyatları ile morfolojik sol ventrikülün sistemik ventrikül, MRV'nin ise pulmonik ventrikül haline dönüștürülmesi amaçlanmıştır. Son 20 yılda double switch ameliyatlarının erken ve orta vadedeki sonuçlarının giderek iyileşmesi, anatomik düzeltmenin tercih edilen bir yöntem olmasına yol açmıştır. Anatomik düzeltme ile ventrikül fonksiyonlarının korunması sayesinde doğuştan cTGA'lı hastaların normal/normale yakın fonksiyonel kapasite ile daha uzun yaşama umutları artmıştır. Ancak kesin bir yargıya varabilmek için daha çok sayıda hastayı kapsayan, daha uzun süreli takipler içeren çalışmalara ihtiyaç vardır.

Anahtar sözcükler: Arteriyal switch; atriyal switch; büyük arterlerin doğuştan düzeltilmiş transpozisyonu; double switch.

(tricuspid) insufficiency after physiologic corrective surgeries are conditions anticipated during the late stage. ${ }^{[1,3-7]}$

Double switch operations have been developed with the aim of providing anatomic repair in cases with congenitally cTGA. The aimed of double switch operations is to convert morphological left ventricular (MLV) into systemic ventricle and MRV into pulmonic

Received: September 28, 2017 Accepted: April 25, 2018

Correspondence: Tayyar Sarıoğlu, MD. Acıbadem Mehmet Ali Aydınlar Üniversitesi Tıp Fakültesi, Kalp ve Damar Cerrahisi Anabilim Dalı, Çocuk Kalp Cerrahisi Bilim Dall, 34752 Ataşehir, İstanbul, Turkey. Tel: +90 216 - 4144408 e-mail: ctsarioglu@gmail.com 
ventricle. By so doing, it is envisaged that the cardiac functions would be secured and life expectancy prolonged. ${ }^{[1,2,7-20]}$

About $50-70 \%$ of patients with congenital cTGA are reported to have wide ventricular septal defect (VSD), whereas approximately $50 \%$ have pulmonary stenosis (valvular, subvalvular stenosis or pulmonary atresia). Atrial situs inversus (ASI) in approximately $5 \%$ of patients, and dextrocardia or mesocardia in $20 \%$ may also be encountered in these patients. Ebstein-like malformation on systemic AV valve and an associated systemic AV valve insufficiency are also observed in a good number of patients. ${ }^{[1,7]}$ The pathophysiology, symptomatology and clinical findings of the patients are dependent on the presence and the type of additional anomalies. The indication, timing and the shape of surgery to be performed is usually determined by additional anomalies.

\section{DOUBLE SWITCH OPERATIONS}

Anatomic corrective surgeries in congenital cTGA, started becoming common place at the beginning of the 1990s due to adverse outcomes observed during the late stage, as a result of physiologic corrective surgery. ${ }^{[2,8,11]}$

\section{Atrial switch - Arterial switch}

Anatomic repair can be achieved by closing the VSD and applying an atrial switch and an arterial switch in congenital cTGA patients with VSD who have normal pulmonary outflow tract and pulmonary valve. ${ }^{[2,9-15]}$ Atrial switch can be performed by either the Senning or Mustard procedure. We prefer the Senning procedure, since we consider it is easier in terms of intracardiac geometry and architecture, and superior in terms of obstruction of venous return and the incidence of arrhythmia. ${ }^{[12,13]}$ We usually perform interatrial re-septation and roofing of pulmonary venous atrium with autologous pericardial patch repair. While creating the systemic venous neo-atrium, the opening to the AV (tricuspid) valve should be at least as large as the tricuspid valve diameter, during direction of the superior vena cava (SVC) and inferior vena cava (IVC) to the MRV (pulmonic ventricle). For this to be achieved, it may be useful to resect the limbus fossa ovalis at the entrance to the SVC and a "cut-back" to the coronary sinus leaving it into the systemic venous atrium. The pulmonary venous chamber outlet should be at least as large as the systemic AV (mitral) valve diameter when directed to the MLV. For this to be achieved, it would be useful to use a pericardial patch repair while extending the interatrial groove incision towards the right upper pulmonary vein and forming the lateral-anterior wall of the pulmonary venous atrium (Figure 1). Special care should be taken not to constrict the normal diameters of the vena cavae by weakening the grip of tourniquet while passing over SVC and IVC. Our experience shows that the presence of ASI and dextrocardia or mesocardia is not an impediment to the Senning operation. ${ }^{[12,13]}$

The VSD is closed relatively easily with single supported stitches through the mitral valve, with the Dacron or Polytetrafluoroethylene (PTFE) patch. When closing the VSD, it should be kept in mind that the anterior AV node and the subsequent His conduction system passes antero-superiorly through the pulmonary annulus and the VSD, and move on the septal surface of the MLV. As a result, it is extremely important to place the sutures from the septal surface of the MRV along the antero-superior rim of the VSD in order to avoid AV block (Figure 2). In patients with sufficiently wide aortic annulus, VSD can also be closed through the aorta. This approach may be safer in terms of protecting the conduction system.

In these time consuming and highly complicated surgeries, we prefer to first carry out the coronary translocation step, which is an important part of arterial switch. Arterial switch is performed using the same technique as in the classical transposition of great arteries (TGA). In cases with congenital cTGA, some minor modifications should be taken into consideration during translocation of coronary arteries. To avoid

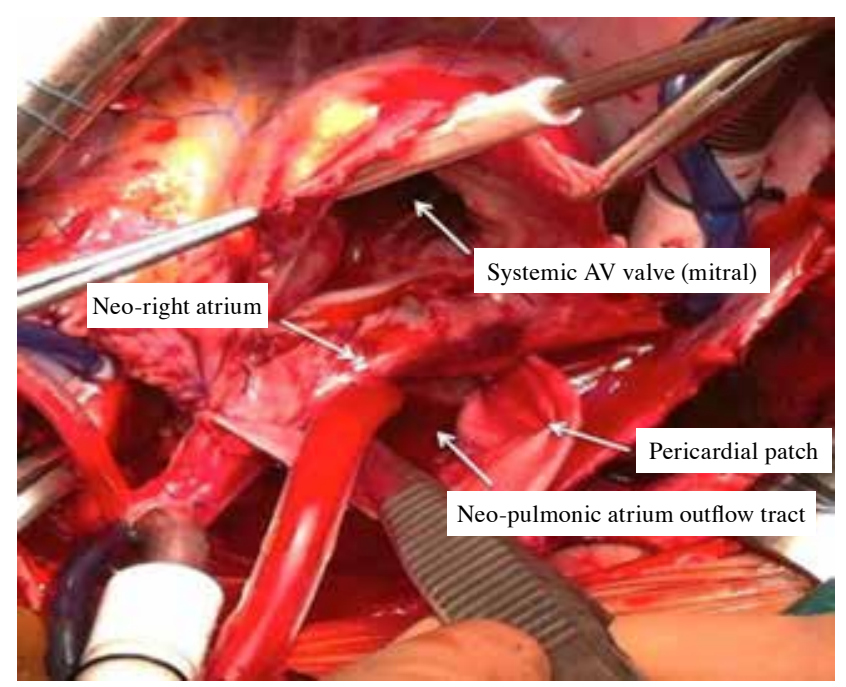

Figure 1. The Senning procedure: The neo-pulmonary atrium is directed to the mitral valve (systemic AV valve) using the pericardial patch attachment to the lateral-anterior wall. (T Sarıoğlu working group archive).

AV: Atrioventricular. 


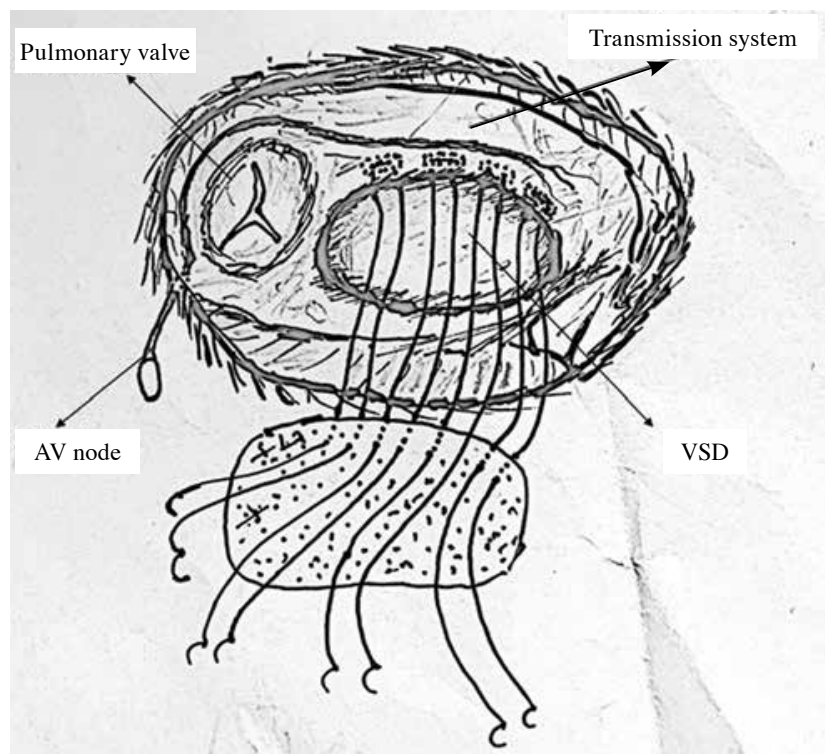

Figure 2. Closure of VSD through the morphological left AV valve (mitral). Atrioventricular transmission system in cases with congenital cTGA is observed on the anterosuperior and MLV septal surface of the pulmonary annulus and VSD.

VSD: Ventricular septal defect; AV: Atrioventricular; cTGA: Corrected transposition of great arteries; MLV: Morphological left ventricle.

tension, twisting and torsion, it may be necessary to prepare coronary buttons as wide as possible, and especially to mobilize the RCA, while sacrificing some small side branches (Figure 3)..$^{[9,11-15]}$ After the translocation of the coronary arteries, we close the VSD and then complete the Senning procedure. Reconstruction of the neo-aorta and neo-pulmonary artery is the last stage of the proceeure. In some cases where the aorta and pulmonary artery are situated side by side, reconstruction of the neo-pulmonary artery without the Lecompte maneuver may be more appropriate with regards to avoid tension and torsion in the pulmonary arteries and absence of pressure on the coronary arteries.

\section{Atrial switch - Ventriculo-arterial switch (Rastelli)}

Patients with congenital cTGA who have pulmonary stenosis together with VSD can undergo anatomical correction with Senning - Rastelli procedure type double switch procedure. ${ }^{[1,8,12-15]}$ In patients with congenital cTGA, VSD is usually large, perimembranous, and has a sub-pulmonic and inlet extension, as seen from MLV. This VSD appears to be located in the subaortic conotruncal region, when viewed from the morphological right ventricle. In the first stage of the surgical operation, the MRV is accessed with an incision on the subaortic region and the MLV is

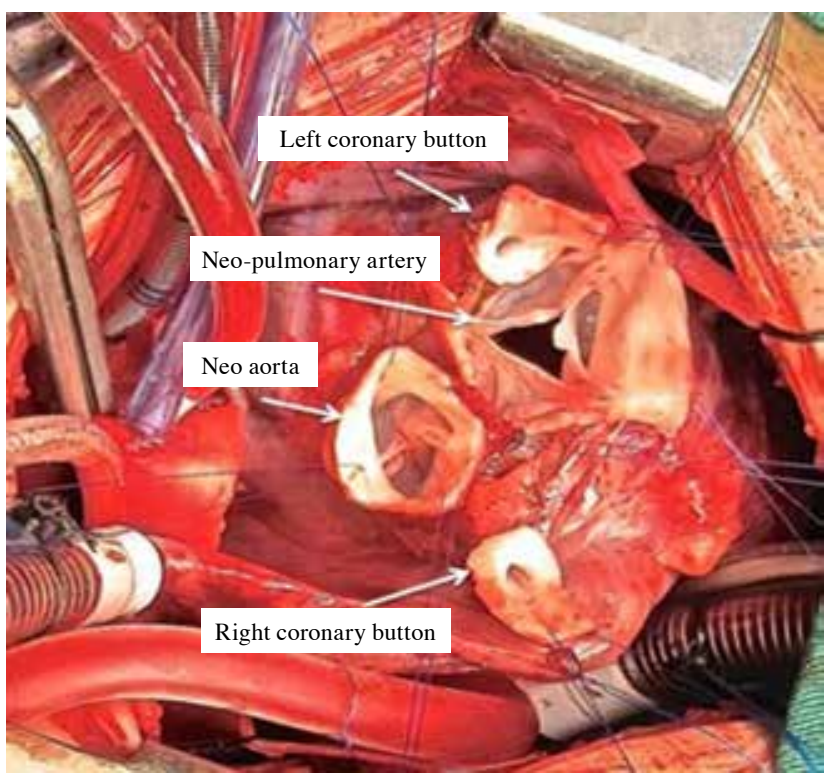

Figure 3. Arterial switch: Aortic and pulmonary artery transection and excision of coronary buttons. (T Sarıoğlu working group archive).

directed to the aorta with the help of intraventricular tunnel through the VSD. This intraventricular tunnel should be placed geometrically with convexity into the MRV, so as not to create any obstruction between the VSD and the aorta (Figure 4a). Since the AV conduction system running on the MLV septal surface, a safer condition is considered with regards to the conduction system while creating intraventricular tunnel. It is easy to create intracardiac tunnel with single pledgetted sutures placing through the septal leaflet of the systemic AV valve. The second step involves application of the atrial switch (Senning) as described above. During the final stage, the pulmonary artery is closed from the ventricular outlet and the MRV-pulmonary artery continuity is provided by an extracardiac conduit (pulmonary homograft or bovine jugular vein [Contegra, Medtronic, Inc., Minneapolis, $\mathrm{MN}]$ ) (Figure 4b). ${ }^{[9,12-15]}$

\section{Senning-Bex-Nikaidoh Procedure}

The Senning-Bex-Nikaidoh procedure is another anatomical correction approach in congenital cTGA patients with concomitant pulmonary stenosis, and particularly restrictive VSD. This procedure has recently been introduced and performed rarely. It is the combination of Senning procedure and the translocation of the aortic root to the MLV outflow (reverse Ross procedure)..$^{[9,15]}$ The main advantage of this approach is that the aortic outflow is made more straight, short and natural. In addition interventricular 

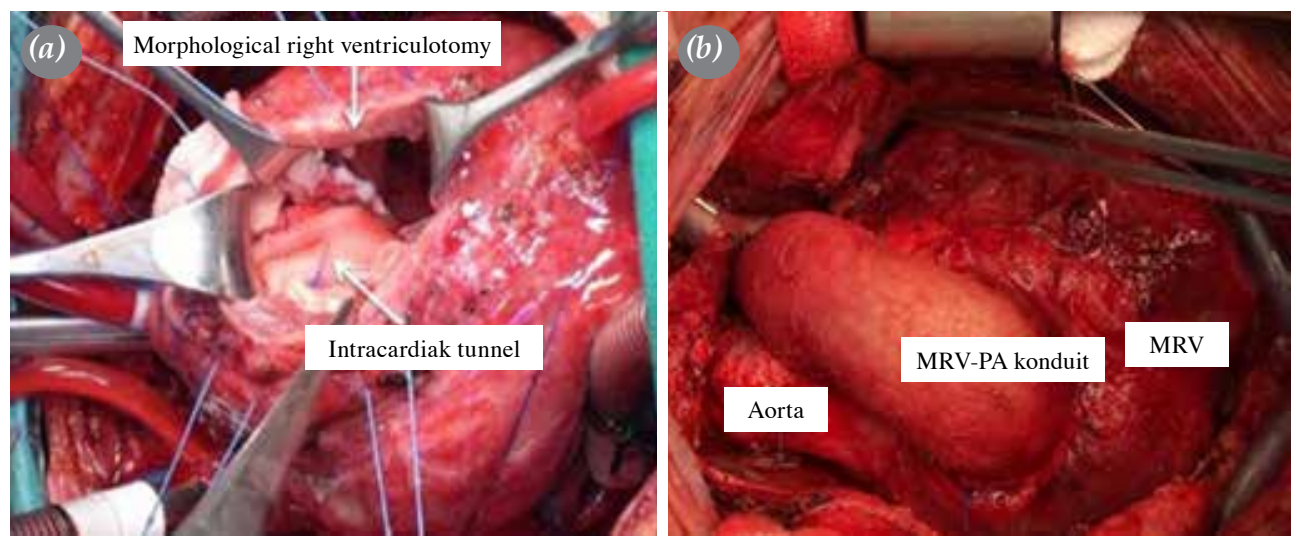

Figure 4. The Senning-Rastelli procedure. (a) Morphological right ventriculotomy is performed with intracardiac tunnel insertion, and the aorta is directed via MLV VSD. (b) MRV-PA extracardiac conduit ( $T$ Sarığglu working group archive).

MLV: Morphological left ventricle; MRV: Morphological right ventricle; VSD: Ventricular septal defect; PA: Pulmonary artery.

septum is easily reconstructed under direct vision, and the MRV-pulmonary artery conduit can be inserted in the orthotopic position away from the sternal compression. However, the division of the outlet septum for the aorta to be translocated to the MLV outlet may result in damage to conduction system which is running through pulmonary annulus and VSD anteriorly. As a result, aortic translocation should be considered in patients who are not anatomically suitable for intracardiac tunnelling. ${ }^{[15]}$ It should be noted that problems and difficulties may also be encountered in coronary transfers in patients with contralateral aortic translocation.

Another alternative, similar to aortic translocation, is the pulmonary translocation approach. With this procedure, the pulmonary annulus is excised from the MLV alongside the muscular subpulmonary surrounding tissue. The VSD is enlarged by posterior division of the outlet septum, taking into account the anterior conduction system. The interventricular defect is repaired with patch, leaving the aorta to the MLV. The defect on MLV roof formed by pulmonary root removal is reconstructed with autologous pericardial patch. By so doing, a direct communication between the MLV and aorta is achieved. Reconstruction of the new right ventricular outflow tract is completed by anastomosing the pulmonary artery to MRV infundibulum. In the meantime, pulmonary annularvalvular stenosis can be enlarged with pericardial monocusped patch. The double switch procedure is then completed with the Senning procedure. There is a need for more time to make an assessment of such approaches, since it has been implemented in only a few cases as described by Da Silva. ${ }^{[16]}$

\section{INDICATION AND TIMING}

Pulmonary hypertension (PH) and congestive heart failure are indications for surgery in congenital cTGA patients with VSD who have normal pulmonary outflow tract. These patients undergo anatomical correction together with Senning procedure and arterial switch by closing the VSD. For this to be achieved, there should be two balanced ventricles and the MLV/MRV pressure ratios must be greater than 0.8 . We generally prefer to perform double switch operations with babies of 3-6 months old. However, it can also be performed during the earlier infancy period if necessary. In older children, care should be taken with regards to cases of inoperability due to irreversible $\mathrm{PH}$ and pulmonary vascular disease.

In congenital cTGA patients with VSD and pulmonary stenosis or pulmonary atresia, we prefer a Senning-Rastelli type double switch operation. For this approach, the location and the size of VSD should be appropriate for the intracardiac tunnel, there should be two proportional and adequately sized ventricles, and the pulmonary vascular structure should be well developed. Since the morphological right ventricular-pulmonary artery continuity would require an extracardiac conduit, it is usually more convenient to implant a larger diameter conduit when the operation is performed after the age of three. ${ }^{[1,8,12,13]}$ When hypoxia and cyanosis are evident in younger infants ( $\mathrm{AO} 2$ saturation $<80 \%$ ), the Senning-Rastelli double switch repair can be performed with a small diameter conduit or systemic to pulmonary shunt can be preferred for palliation. The Senning-BexNikaidoh procedure may be considered as an option in the patients with concomitant pulmonary stenosis and restrictive VSD. 
Overriding-straddling of atrioventricular valves and hypoplasia of one of the ventricles constitute the main contraindication for double switch operations. In patients with single ventricular pathology and pulmonary stenosis, systemic to pulmonary shunt operation is performed before the age of six months. Following shunt operation, bidirectional cavapulmonary anastomosis and Fontan type univentricular repair approaches are applied when needed. In the absence of pulmonary stenosis, pulmonary banding is performed during the neonatal period, followed by the single ventricular repair steps.

\section{OPERATIVE STRATEGY}

Standard cardiopulmonary bypass is initiated with median sternotomy, direct cannulation of SVC and IVC, and distal aortic cannulation. We prefer isothermic intermittent blood cardioplegia with $26-28^{\circ} \mathrm{C}$ systemic hypothermia and intermittent low flow cardiopulmonary bypass to provide a better view. In the Senning-arterial switch procedure, we first complete the coronary translocation step of the arterial switch, while in the Senning-Rastelli procedure we first complete the intraventricular tunnel followed by the Senning procedure. Transesophageal echocardiography (TEE) and cerebral $\mathrm{O}_{2}$ saturation monitoring (NIRS) should be routinely performed in the operating room. Cell saver, apheresis thrombocyte, surgical adhesives, hemofiltration and extracorporeal membrane oxygenation (ECMO) should be made available in the operating room. It is advisable to use an adhesion barrier or "pericardial substitute" with regards to possibility of reoperations. It is more appropriate to postpone closing the sternum for 24 to 48 hours postoperatively for the patients with unstable hemodynamic status.

We routinely use nitric oxide, deep sedation and keep the patient under mild respiratory alkalosis to prevent pulmonary hypertensive crises in patients undergoing an atrial and arterial switch operation with VSD and PH for the first postoperative 48-72 hours. Continuous monitoring of pulmonary artery pressure by placing a pulmonary artery catheter is important with regards to the prevention and management of pulmonary hypertensive crisis, particularly when weaning for extubation.

In general, it may be necessary to keep patients under sedation for 24-48 hours, maintaining moderate dose inotropic (milrinone + dopamine/ adrenaline) support. Aspirin and low molecular weight heparin treatment is continued for 7-10 days starting from the first postoperative day and the treatment protocol is continued with aspirin and/or clopidogrel.

\section{Sample cases}

1. Senning-Arterial switch: A 17-month-old boy with congestive heart failure. The patient was diagnosed with ASI, congenital cTGA, VSD and PH by echocardiography. The diagnosis was confirmed by angiocardiography and catheterization. The VSD was perimembranous, subpulmonic and with inlet extension. There was severe left to right shunt; (QP/ QS:3.5). The pulmonary outflow tract and pulmonary valve were found to be normal. The MRV and MLV were well developed. Morphological left ventricular and pulmonary artery pressures were at a systemic level. The usual inverted coronary arterial structure was present.

Anatomical correction by Senning procedure and arterial switch was performed (This is the first patient in Turkey undergone double switch operation, July 20, 1995). The VSD was transatrially closed with a Dacron patch through the mitral valve. The early postoperative period was normal. Sinus rhythm was preserved. The patient was found to have died in his sleep one night at the $12^{\text {th }}$ year after surgery (Arrhythmia? Sudden death?). By then, the patient survived with NYHA (New York Heart Association) Class I-II functional capacity and normal ventricular and valvular function without any medication.

2. Senning-Rastelli: A 12-year-old girl presented with symptoms of severe cyanosis and hypoxia. Echocardiography revealed ASI, dextrocardia, congenital cTGA, VSD and pulmonary atresia. The diagnosis was confirmed by angiocardiography and catheterization (Figure 5a). The Senning-Rastelli procedure was performed (This patient was the first patient in Turkey to be subjected to the Senning procedure from the left side due to ASI, October 24, 1995). The Medtronic Freestyle heterograft was used as a morphological right ventricular-pulmonary artery conduit (Medtronic, Inc., Minneapolis, MN, USA) (Figure 5b, c). The postoperative period was uneventful. Sinus rhythm was preserved. Follow-up of the patient has been discontinued 11 years after the surgery, while being followed up with normal cardiac function and with a functional capacity of NHYA Class-I.

3. Senning-Rastelli: A six-year-old boy, who underwent central shunt operation at the age of three days, due to deep hypoxic spell. Right atrial isomerism, dextrocardia, ventriculoarterial discordance, VSD and pulmonary atresia were diagnosed by echocardiography and confirmed by angiography. At the age of six years, 

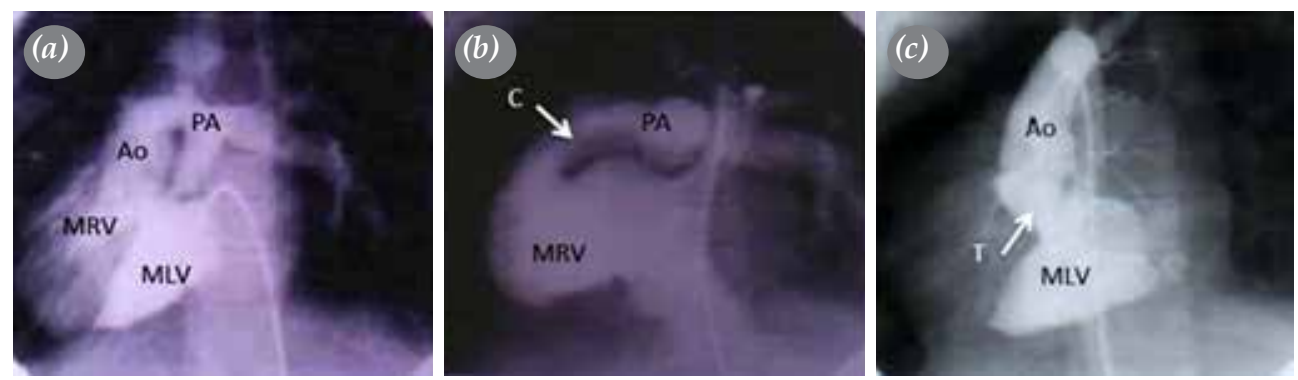

Figure 5. The double switch operation (Senning-Rastelli): (a) Preoperative angiocardiography; ASI, dextrocardia, congenital cTGA, VSD, PS. (b) Postoperative angiocardiography; MRV-PA extracardiac conduit. (c) Postoperative angiocardiography; MLV-aortic intracardiac tunnel.

ASI: Atrial situs inversus; cTGA: corrected transposition of great arteries; VSD: Ventricular septal defect; PS: Pulmonary stenosis; MRV: Morphological right ventricle; PA: Pulmonary artery.

he underwent Senning-Rastelli type double switch operation (November 03, 2000). Nine years after the double switch operation, supraventricular arrhythmia attacks occurred in the patient. It was then returned to sinus rhythm after the electrophysiological study and catheter ablation. The RV-pulmonary artery conduit (Medtronic Freestyle porcine aortic heterograft), which was calcified after 15 years of double switch operation, was replaced by pulmonary homograft. The patient is currently 21 years old and continues to live with an NYHA Class I-II functional capacity.

\section{Cumulative experience}

A total of 20 patients underwent double switch surgery between January 1995 and May 2017. The ages of the patients ranged from 4 months to 13 years (median age 6 years). The Senning-Rastelli procedure was performed in 17 patients and Senning-arterial switch procedure in three patients, one of which included Glenn take-down. Three patients had ASI with dextrocardia while six had isolated dextrocardia/ mesocardia. Three patients died during the early period (15\%). Three patients (two during the late stage) needed a permanent pacemaker. One patient underwent reoperation sixth year after surgery due to intracardiac tunnel narrowing. Three patients underwent pulmonary conduit replacement after 8,10 , and 15 years, respectively after double switch operation.

\section{PHYSIOLOGICAL CORRECTION? ANATOMICAL CORRECTION?}

According to the data obtained, it is generally accepted that double switch (anatomical correction) operations in patients with congenital cTGA are superior to physiological repair in the mid-long term, in terms of systemic $\mathrm{AV}$ valve and systemic ventricular functions. ${ }^{[1,8-10,14,15,18-23]}$
Double switch operations are time consuming complex procedures with a high morbidity rate. Although the hospital mortality rate is low in some studies (0-7.9\%), according to the common database of The Society of Thoracic Surgeons - The European Association for Cardio-Thoracic Surgery (STS-EACTS), it is suggested to range between 9.1 to $37.2 \%$ (95\% interval). ${ }^{[8,18-20,24]}$ According to 5 and 10 years follow-up results after anatomical correction, survival rates are $90 \%$ and $85 \%$, respectively, without systemic ventricular dysfunction. ${ }^{[1,2,8,18-20]}$ As one of the most recent data, Hraska et al. ${ }^{[23]}$ reported that $93 \%$ of survival and systemic ventricular function could be maintained for 15 years after anatomic correction. According to these results, considering the problems related to late systemic ventricle and tricuspid valve dysfunction after physiological correction compared to early morbidity and mortality risk of anatomical correction, double switch operations have become more preferred procedure. However, patients should be monitored carefully in terms of arrhythmia, neoaortic valve insufficiency, ventricular dysfunction and pulmonary conduit complications. It is inevitable to re-replace the conduit in the long period of SenningRastelli procedure. However, over the ten years postoperatively, we may say that there is no need to re-replace the pulmonary conduit more than $60 \%{ }^{[1,8,20]}$

We believe that some initiatives in the context of physiological repair, which have recently been suggested, should be taken into consideration. Some groups who consider double switch approaches to be complex and risky, suggest that a moderate pulmonary banding may be beneficial in patients with congenital cTGA who have systemic AV valve insufficiency and ventricular dysfunction after physiological repair. ${ }^{[26]}$ By so doing, increasing the pulmonic ventricular pressure (MLV), pushing 
the interventricular septum towards the systemic ventricle (MRV) can improve systemic ventricular dilatation and tricuspid valve insufficiency. ${ }^{[19,25]}$ In addition, in some patients with pulmonary stenosis, there are studies suggesting permanent palliation with the "one-and-a-half ventricle" approach by performing bidirectional cavopulmonary anastomosis. Hence, while maintaining adequate pulmonary flow, preservation of the geometry of the interventricular septum is considered, allowing for some residual pulmonary stenosis. ${ }^{[19,27]}$

The two-stage double switch approach should be considered as a separate category: In patients with isolated congenital cTGA, a two-stage arterial switch procedure is indicated if systemic ventricular and tricuspid valve dysfunction develops, or if MRV dysfunction occurs in patients with TGA who had previously undergone atrial switch. As a result, retraining the MLV by pulmonary banding in advance, which will assume the systemic ventricular function, is necessary. The MLV may be able to function against systemic pressures within a time interval of three weeks to 6-9 months after the pulmonary banding procedure (retraining of MLV). After the retraining procedure the objective is to maintain the MLV/MRV pressure ratio greater than 0.8 and the MLV mass/volume index greater than 1.5. ${ }^{[15,17]}$ However, in patients who underwent the double switch operation after the retraining procedure, there are concerns that the mid and long term performance of the systemic ventricle (MLV) may not be as expected. ${ }^{[4,17,19]}$ And although the retraining procedure improves systolic ventricular function, pathologic ventricular mass which arise due to myocardial hypertrophy has been shown to cause diastolic dysfunction.

On the other hand, it is suggested that the retraining procedure is more effective in little babies (before the age of 2 years), but may not be benefited especially if they are performed after 15 years of age. ${ }^{[4,17,19]}$

\section{What have we learned?}

1. In patients with congenital cTGA, anatomical correction seems to gain importance in terms of the preservation of ventricular function and longterm survival when compared to conventionalphysiological correction approaches.

2. Procedures such as pulmonary banding, 1.5-ventricle type repair are remarkable and the long term results should be followed.

3. In order to make a definite judgment about double switch operations, there is a need longer follow-up studies with a lager sample size patient data.
4. In two-stage double switch operations; concerns about long-term outcomes of left ventricular function should be taken into nconsideration. It should not be ignored that it may not be effective, especially in older children.

5. Patients undergone double switch operation should be carefully monitored during the late stage, with regards to ventricular functions, rhythm problems, neoaortic insufficiency, and complications of pulmonary conduit.

\section{Declaration of conflicting interests}

The authors declared no conflicts of interest with respect to the authorship and/or publication of this article.

\section{Funding}

The authors received no financial support for the research and/or authorship of this article.

\section{REFERENCES}

1. Kouchoukos NT, Blackstone EH, Hanley FL, Kirklin JK, editors. Congenitally corrected transposition of the great arteries and other forms of atrioventricular discordant connection. In: Kirklin/Barratt-Boyes Cardiac Surgery. Philadelphia: Elsevier Saunders; 2013. p. 1971-2003.

2. Ilbawi MN, DeLeon SY, Backer CL, Duffy CE, Muster AJ, Zales VR, et al. An alternative approach to the surgical management of physiologically corrected transposition with ventricular septal defect and pulmonary stenosis or atresia. J Thorac Cardiovasc Surg 1990;100:410-5.

3. Hraska V, Duncan BW, Mayer JE Jr, Freed M, del Nido PJ, Jonas RA. Long-term outcome of surgically treated patients with corrected transposition of the great arteries. J Thorac Cardiovasc Surg 2005;129:182-91.

4. Lim HG, Lee JR, Kim YJ, Park YH, Jun TG, Kim WH, et al. Outcomes of biventricular repair for congenitally corrected transposition of the great arteries. Ann Thorac Surg 2010;89:159-67.

5. Sano T, Riesenfeld T, Karl TR, Wilkinson JL. Intermediateterm outcome after intracardiac repair of associated cardiac defects in patients with atrioventricular and ventriculoarterial discordance. Circulation 1995;92:272-8.

6. van Son JA, Danielson GK, Huhta JC, Warnes CA, Edwards WD, Schaff HV, et al. Late results of systemic atrioventricular valve replacement in corrected transposition. J Thorac Cardiovasc Surg 1995;109:642-52.

7. Brawn WJ, Jones TJJ, Anderson RH, Barron DJ. Congenitally corrected transposition. In: Anderson RH, Baker EJ, Penny D, Redington AN, Rigby ML, Wernonovsky G, editors. Pediatric Cardiology. Philadelphia: Churchill Livingstene Elsevier; 2010. p. 819-35.

8. Brawn WJ. The double switch for atrioventricular discordance. Semin Thorac Cardiovasc Surg Pediatr Card Surg Annu 2005:51-6.

9. El-Zein C, Subramanian S, Ilbawi M. Evolution of the surgical approach to congenitally corrected transposition of 
the great arteries. Semin Thorac Cardiovasc Surg Pediatr Card Surg Annu 2015;18:25-33.

10. Bilal MS, Avşar MK, Yıldırım Ö, Özyüksel A, Zeybek C, Küçükosmanoğlu O, et al. Double Switch Procedure and Surgical Alternatives for the Treatment of Congenitally Corrected Transposition of the Great Arteries. J Card Surg 2016;31:231-6.

11. Karl TR, Weintraub RG, Brizard CP, Cochrane AD, Mee RB. Senning plus arterial switch operation for discordant (congenitally corrected) transposition. Ann Thorac Surg 1997;64:495-502.

12. Sarığlu T, Erek E. Büyük arterlerin transpozisyonunda anatomik düzeltme. Türkiye Klinikleri Kardiyoloji Dergisi; (T Klin J Cardiol), 2003;16:347-54.

13. Erek E, Sarığlu T, Büyük arterlerin transpozisyonu. In: Paç M, Akçevin A, Aka SA, Büket S, Sarıoğlu T, editor. Kalp Damar Cerrahisi. 2. Bask1. Ankara: MN Medikal \& Nobel 2013. s. 2027-37.

14. Mee RB. The double switch operation with accent on the Senning component. Semin Thorac Cardiovasc Surg Pediatr Card Surg Annu 2005:57-65.

15. Hraska V, Murin P. Surgical Management of Congenital Heart Disease I. Berlin: Springer. 2012.

16. Da Silva JP, Da Silva LF, Baumgratz JF, Castro RM, Bezerra RF, Guilhen JC. Root translocation in congenitally corrected transposition of the great arteries with ventricular septal defect and pulmonary stenosis, and other lesions. Semin Thorac Cardiovasc Surg Pediatr Card Surg Annu 2015;18:34-9.

17. Quinn DW, McGuirk SP, Metha C, Nightingale $P$, de Giovanni JV, Dhillon R, et al. The morphologic left ventricle that requires training by means of pulmonary artery banding before the double-switch procedure for congenitally corrected transposition of the great arteries is at risk of late dysfunction. J Thorac Cardiovasc Surg 2008;135:1137-44.

18. Ly M, Belli E, Leobon B, Kortas C, Grollmüss OE, Piot D, et al. Results of the double switch operation for congenitally corrected transposition of the great arteries. Eur J Cardiothorac Surg 2009;35:879-83.
19. Jonas RA, editor. Congenitally corrected transposition of the great arteries. In: Comprehensive surgical management of Congenital heart disease. 2nd ed. Boca Raton: CRC Press; 2014. p. 644-6. p. 483-498.

20. Murtuza B, Barron DJ, Stumper O, Stickley J, Eaton D, Jones TJ, et al. Anatomic repair for congenitally corrected transposition of the great arteries: a single-institution 19-year experience. J Thorac Cardiovasc Surg 2011;142:1348-57.

21. Erek E, Yalcinbas YK, Salihoglu E, Ozturk N, Arat S, Sarioglu A, et al. Fate of stentless bioprostheses on right side of the heart. Asian Cardiovasc Thorac Ann 2003;11:58-62.

22. Imai Y, Seo K, Aoki M, Shin'oka T, Hiramatsu K, Ohta A. Double-Switch operation for congenitally corrected transposition. Semin Thorac Cardiovasc Surg Pediatr Card Surg Annu 2001;4:16-33.

23. Hraska V, Vergnat M, Zartner P, Hart C, Suchowerskyj $\mathrm{P}$, Bierbach B, et al. Promising Outcome of Anatomic Correction of Corrected Transposition of the Great Arteries. Ann Thorac Surg 2017;104:650-6.

24. O'Brien SM, Clarke DR, Jacobs JP, Jacobs ML, LacourGayet FG, Pizarro C, et al. An empirically based tool for analyzing mortality associated with congenital heart surgery. J Thorac Cardiovasc Surg 2009;138:1139-53.

25. Ma K, Gao H, Hua Z, Yang $K$, Hu S, Zhang $H$, et al. Palliative pulmonary artery banding versus anatomic correction for congenitally corrected transposition of the great arteries with regressed morphologic left ventricle: long-term results from a single center. $\mathrm{J}$ Thorac Cardiovasc Surg 2014;148:1566-71.

26. Kral Kollars CA, Gelehrter S, Bove EL, Ensing G. Effects of morphologic left ventricular pressure on right ventricular geometry and tricuspid valve regurgitation in patients with congenitally corrected transposition of the great arteries. Am J Cardiol 2010;105:735-9.

27. Mavroudis C, Backer CL. Physiologic versus anatomic repair of congenitally corrected transposition of the great arteries. Semin Thorac Cardiovasc Surg Pediatr Card Surg Annu 2003;6:16-26. 